\title{
Perlindungan Hak Cipta Penerbit terhadap Buku Ciptaan yang Telah Menjadi Public Domain
}

\section{Muh. Aldhyansah Dodhy Putra}

Universitas Indonesia

\section{Contact: muh.aldhyansah@ui.ac.id}

Diterima: 16 Desember 2020

Direvisi:

Disetujui: 30 Desember 2020 Hak Cipta: (C2018

Halaman: 81-92

\begin{abstract}
Act Number 28 of 2014 on Copyright regulates changes in the period of protection of a work. One of them is about books, which were previously protected 50 years after the author's death was amended to 70 years after the author's death in Article 58 (1) of Act Number 28 of 2014 on Copyright. This change not only has implications for increasing the length of time to protect many of the late author's works but also creates new confusion regarding the status of authors who have died more than 50 years before the enactment of the law. This regulatory change has led to research on the protections that publishers have for books with expired protection period (public domain). The method used in this research is juridical-normative research, which examines several regulations, especially Act Number 28 of 2014 on Copyright. The results show that publishers can obtain copyright protection for public domain books as long as they do not violate moral rights and that there are common misconceptions regarding the length of time for book copyright protection due to regulation changes.
\end{abstract}

Keywords: Copyright, Public Domain, Publisher. 


\section{PENDAHULUAN}

Istilah hak cipta pertama kali dikemukakan melalui kongres kebudayaan di Bandung tahun 1951, oleh Prof. Moh. Soetan Moh. Sjah, yang kemudian diterima sebagai pengganti istilah Hak Mengarang yang dianggap kurang luas cakupan pengertiannya. Istilah hak mengarang merupakan terjemahan dari Auteurs Recht. Karena memberikan kesan bahwa ada penyempitan arti seolah-olah yang dicakup hak pengarang itu hanyalah hak pengarang saja, atau yang ada sangkut pautnya dengan karang mengarang, sedang istilah hak cipta itu lebih luas dan di dalamnya mencakup tentang karang mengarang, sehingga istilah hak cipta digunakan dan dipakai dalam undangundang hak cipta Indonesia (Ashilby, 2016: 45).

Sejak masa itu pula, pemerintah Republik Indonesia telah beberapa kali merancang dan merevisi peraturan tentang hak cipta. Dikarenakan semakin berkembangnya Indonesia, semakin berkembang pula kemampuan teknologi informasi dan komunikasi mengharuskan adanya pembaruan Undang-Undang Hak Cipta. Hingga yang terbaru ialah Undang-Undang Nomor 28 Tahun 2014 tentang Hak Cipta (UUHC 2014) yang menggantikan UndangUndang Nomor 19 Tahun 2002 tentang Hak Cipta (UUHC 2002).

Pergantian UUHC 2002 ke UUHC 2014 telah melahirkan perubahan pada beberapa norma hukum. Salah satunya ialah tentang masa berlaku perlindungan hak ekonomi terhadap beberapa jenis ciptaan termasuk di dalamnya ialah buku. Jika pada Pasal 29 (1) UUHC 2002 hak ekonomi atas buku berlaku hingga 50 tahun setelah pencipta meninggal dunia, oleh Pasal 58 (1) UUHC 2014 diberi jangka waktu perlindungan yang lebih lama yakni 70 tahun setelah pencipta meninggal dunia.

Buku-buku yang telah berakhir jangka waktu perlindungan hak ekonominya dianggap telah menjadi domain publik (public domain). Public domain adalah istilah yang merujuk pada seluruh karyakarya kreatif dan intelektual yang telah menjadi milik bersama karena tidak dilindungi atau tidak lagi dilindungi oleh undang-undang hak cipta yang ekslusif (Fitriayu Penyalai, 2020: 1). Hasil karya yang ada dalam domain publik dianggap sebagai bagian dari warisan budaya masyarakat dan setiap orang dapat menggunakannya secara bebas dan legal untuk tujuan apa pun tanpa perlu meminta izin terlebih dahulu.

Saat ini terdapat banyak buku yang telah menjadi public domain. Beberapa di antaranya ialah buku Max Havelaar karangan Multatuli maupun Madilog karangan Tan Malaka. Buku-buku tersebut, meski telah menempuh beberapa zaman masih tetap mudah ditemukan hingga saat ini. Tidak perlunya ada pembayaran royalti membuat banyak penerbit memilih untuk terus mencetak ulang buku-buku tersebut. Lihat saja buku Max Havelaar yang saat ini masih beredar di Indonesia dalam naungan beberapa penerbit seperti Mizan Publishing, Media 
Pressindo, Qanita, dan lain-lain.

Berakhirnya hak eksklusif pencipta buku memang berarti keuntungan bagi penerbit, terlebih dengan adanya kemudahan izin penerbitan. Namun tak berarti tidak ada permasalahan hukum yang dapat dikaji terkait ciptaan yang telah menjadi public domain. Masih terdapat beberapa masalah yang perlu dianalisis yaitu; (1) Bagaimana perlindungan hak cipta bagi penerbit terhadap buku yang telah menjadi public domain? (2) Bagaimana pengaturan jangka waktu perlindungan hak pencipta buku setelah adanya perubahan dari UUHC sebelumnya ke UUHC 2014 ?

\section{METODOLOGI PENELITIAN}

Penelitian ini akan menggunakan metode kualitatif dengan pendekatan normatif yuridis, yaitu penelitian yang menggunakan dokumen atau kepustakaan. Penelitian hukum normatif disebut juga penelitian hukum doktrinal. Menurut Peter Mahmud Marzuki (2010), penelitian hukum normatif adalah suatu proses untuk menemukan suatu aturan hukum, prinsip-prinsip hukum, maupun doktrin-doktrin hukum guna menjawab isu hukum yang dihadapi. Penelitian hukum yuridis sendiri bermakna penelitian mencakup penelitian penelitian terhadap azas-azas hukum, sistematika hukum, taraf sinkronisasi hukum, sejarah hukum, dan perbandingan hukum.

Sumber utama dalam penelitian ini ialah bahan hukum primer berupa UndangUndang Hak Cipta Nomor 12 Tahun 1997 tentang Perubahan Atas Undang-Undang Nomor 6 Tahun 1982 tentang Hak Cipta (UUHC 1997); UUHC 2002; UUHC 2014; dan Kitab Undang-Undang Hukum Perdata (KUHPer). Bahan hukum sekunder dalam penelitian dikumpulkan melalui studi pustaka, yang meliputi buku, jurnal, dan hasil penelitian yang relevan. Penelitian ini berguna untuk menghasilkan preskripsi atas isu yang dibahas, khususnya tentang perlindungan hak cipta penerbit terhadap buku ciptaan yang telah menjadi public domain.

\section{HASIL DAN PEMBAHASAN}

\section{Perlindungan Hak Cipta Bagi Penerbit Terhadap Buku yang Telah Menjadi Public Domain}

\section{Hak Ekonomi dan Lisensi Penerbit}

Penerbitan buku ialah bentuk pemanfaatan hak ekonomi ciptaan. Hak ekonomi sendiri merupakan hak eksklusif Pencipta atau Pemegang Hak Cipta untuk mendapatkan manfaat ekonomi atas Ciptaan.

Pada Pasal 8 UUHC disebutkan bahwa Hak ekonomi untuk memperoleh keuntungan finansial dari perolehan pengakuan hak kekayaan intelektual berupa pengalihan dan pemberian izin dari penggunaan HKI-nya dengan memperoleh royalti. Lebih jelasnya, hak ekonomi adalah hak yang dimiliki oleh pencipta atau pemegang hak cipta untuk mendapat manfaat ekonomi dari ciptaannya, atau hak mengizinkan atau melarang orang lain untuk 
mengumumkan dan/atau memperbanyak ciptaannya. (Khoirul Hidayah, 2012: 50-51).

Hak ekonomi ini pada setiap UUHC selalu berbeda, baik terminologinya, jenis hak yang diliputinya, ruang lingkup dari tiap jenis hak ekonomi tersebut. Secara umumnya setiap negara, minimal mengenal, dan mengatur hak ekonomi tersebut meliputi jenis hak.

1) Hak reproduksi atau penggandaan (reproduction right). Hak reproduksi sama dengan perbanyakan, yaitu menambah jumlah suatu penciptaan dengan pembuatan yang sama, hampir sama, atau menyerupai ciptaan tersebut dengan menggunakan bahan-bahan yang sama maupun tidak sama, termasuk mengalihwujudkan sesuatu ciptaan.

2) Hak adaptasi (adaptation rights) dapat berupa penerjamahan dari bahasa satu ke bahasa lain, aransemen musik, dramatisasi dari non dramatik, mengubah menjadi cerita fiksi dari karangan non fiksi, dan sebaliknya.

3) Hak distribusi (distribution rights) yakni hak yang dimiliki pencipta untuk menyebarkan kepada masyarakat setiap hasil ciptaannya. Penyebaran tersebut dapat berupa bentuk penjualan, penyewaan, atau bentuk lain yang dimaksudnya agar ciptaan tersebut dikenal oleh masyarakat.
4) Hak pertunjukan (public performance rights) yang dimiliki oleh para pemusik, dramawan, maupun seniman lainnya yang karyanya dapat terungkapkan dalam bentuk pertunjukan.

5) Hak penyiaran (broadcasting rights) yang bentuknya berupa mentransmisikan suatu ciptaan oleh peralatan tanpa kabel. Hak penyiaran ini meliputi penyiaran ulang dan mentransmisikan ulang.

6) Hak program kabel (cable casting rights) yang hampir sama dengan hak penyiaran hanya saja mentransmisikannya melalui kabel.

7) Droit de suite yakni hak pencipta yang bersifat kebendaan.

8) Hak pinjam masyarakat (public lending rights) merupakan hak yang dimiliki oleh pencipta yang karyanya tersimpan di perpustakaan, yaitu dia berhak atas suatu pembayaran dari pihak tertentu karya yang diciptakannya sering dipinjam oleh masyarakat dari perpustakaan milik pemerintah tersebut. (Ashilby: 6571).

Hak ekonomi apa saja yang dimiliki oleh pencipta dan pemegang hak cipta juga diatur pada Pasal 9 UUHC yaitu:

a. penerbitan Ciptaan;

b. Penggandaan Ciptaan dalam segala bentuknya;

c. penerjemahan Ciptaan;

d. pengadaptasian, 
pengaransemenan, atau pentransformasian Ciptaan;

e. Pendistribusian Ciptaan atau salinannya;

f. pertunjukan Ciptaan;

g. Pengumuman Ciptaan;

h. Komunikasi Ciptaan; dan

i. penyewaan Ciptaan.

Penerbit sendiri memperoleh hak ekonomi melalui pemberian lisensi oleh pemegang hak cipta. Oleh karenanya, sebelum memahami bagaimana perlindungan hak cipta penerbit terhadap ciptaan public domain ada baiknya diuraikan terlebih dahulu tentang penerimaan lisensi oleh penerbit.

Sebagaimana diatur dalam Pasal 80 (3), penerima lisensi wajib untuk memberikan royalti kepada pemegang hak cipta kecuali jika diperjanjikan lain. Besar nominal royalti sendiri dilakukan berdasarkan perjanjian lisensi dan harus ditetapkan berdasarkan kelaziman praktik yang memenuhi unsur keadilan.

Jenis hak dan kewajiban para pihak dalam suatu perjanjian lisensi dapat ditetapkan secara bebas sesuai dengan kehendak para pembuat perjanjian lisensi tersebut. Hal ini sesuai dengan asas kebebasan berkontrak sebagai salah satu asas hukum perdata positif yang berlaku di Indonesia. Asas kebebasan berkontrak memberikan kebebasan yang sangat luas kepada individu untuk mengatur hak dan kewajiban para pihak dalam suatu perjanjian.

Dalam hukum positif Indonesia, asas kebebasan berkontrak diatur dalam Pasal 1338 ayat (1) KUH Perdata yang mengatur bahwa setiap perjanjian yang dibuat secara sah berlaku sebagai undang-undang bagi para pihak yang membuatnya. Dalam hubungan dengan penjelasan tentang pembatasan penerapan asas kebebasan berkontrak yang dikemukakan di atas dapat dikemukakan pendapat Subekti yang berpendapat bahwa "...Pasal tersebut (maksudnya Pasal 1338 ayat (1) KUH Perdata) seolah-olah berisikan suatu pernyataan kepada masyarakat bahwa kita diperbolehkan membuat perjanjian yang berupa dan berisi apa saja (atau tentang apa saja) dan dengan perjanjian itu akan mengikat mereka yang membuatnya seperti suatu undangundang". Namun, Pasal 1338 ayat (1) KUH Perdata tersebut tidak bisa diartikan sangat luas sehingga para pihak seolah-olah dapat membuat suatu perjanjian mengenai apapun sesuai dengan kehendak mereka yang membuat perjanjian tersebut

(Anis Mashdurohatun, 2018: 204).

Karena bentuknya perjanjian maka untuk syarat sahnya wajib memenuhi syarat-syarat yang ditetapkan berdasarkan Pasal 1320 KUH Perdata, syarat sahnya perjanjian adalah sepakat mereka yang mengikatkan diri, memiliki kecakapan, hal tertentu, dan sebab yang halal. Di samping syarat sahnya perjanjian, harus diperhatikan bahwa berdasarkan Pasal 584 KUH Perdata, suatu pengalihan hak selain harus didasarkan pada perjanjian yang dibuat secara sah sebagai alas hak atau titel 
yang sah, juga harus dilakukan oleh pihak yang berwenang mengalihkan hak tersebut. Ketentuan ini merupakan penerapan dari asas nemo plus iuris in alium transferee potest quam ipse hibet. Artinya, tiada seorang pun yang dapat menyerahkan hak-haknya kepada orang lain melebihi dari hak yang dimilikinya (Anis Mahdurobatun: 205-207). Pengaturan pasal 584 sejalan dengan pengaturan Pasal 82 (3) bahwa Perjanjian Lisensi dilarang menjadi sarana untuk menghilangkan atau mengambil alih seluruh hak Pencipta atas Ciptaannya.

Pasal 18 UUHC sebenarnya mengatur adanya pengalihan Ciptaan buku dalam perjanjian jual putus dan/atau pengalihan tanpa batas waktu. Hak Ciptanya beralih kembali kepada Pencipta pada saat perjanjian tersebut mencapai jangka waktu 25 (dua puluh lima) tahun. Sedangkan yang dimaksud dengan "jual putus" adalah perjanjian yang mengharuskan Pencipta menyerahkan Ciptaannya melalui pembayaran lunas oleh pihak pembeli sehingga hak ekonomi atas Ciptaan tersebut beralih seluruhnya kepada pembeli tanpa batas waktu, atau dalam praktik dikenal dengan istilah (sold flat).

Demi mampu menjalankan usaha secara optimal Penerbit menjalankan praktiknya dibantu oleh Ikatan Penerbit Indonesia (IKAPI). IKAPI merupakan wadah kumpulan dari penerbit-penerbit selaku pemegang hak cipta atas karya buku. Di dalam ketentuan Pasal 1 angka 4 UU No 28 Tahun 2014 tentang Hak Cipta, Pemegang Hak Cipta adalah
Pencipta sebagai pemilik Hak Cipta, pihak yang menerima hak tersebut secara sah dari Pencipta, atau pihak lain yang menerima lebih lanjut hak dari pihak yang menerima hak tersebut secara sah (Anis Masdurohatun: 188).

Perlindungan hak ekonomi bagi penerbit khususnya pada jenis pelanggaran Pasal 9 ayat (1) tentang penerbitan Ciptaan, Penggandaan Ciptaan dalam segala bentuknya, Pendistribusian Ciptaan atau salinannya, Pengumuman Ciptaan diatur dalam Pasal 113 (3) UUHC 2014. Untuk penggunaan secara komersial dipidana dengan pidana penjara paling lama 4 (empat) tahun dan/atau pidana denda paling banyak Rp1.000.000.000,00 (satu miliar rupiah). Kemudian bagi setiap orang yang memenuhi unsur sebagaimana dimaksud Pasal 113 (3) tersebut yang dilakukan dalam bentuk pembajakan, disanksi lebih berat dengan pidana penjara paling lama 10 (sepuluh) tahun dan/atau pidana denda paling banyak Rp 4.000.000.000,00 (empat miliar rupiah). Pembajakan yang dimaksud dalam ayat tersebut ialah penggandaan Ciptaan dan/atau produk Hak Terkait secara tidak sah dan pendistribusian barang hasil penggandaan dimaksud secara luas untuk memperoleh keuntungan ekonomi.

Kemudian diatur bahwa setiap Orang yang tanpa izin Pencipta atau Pemegang Hak Cipta dilarang melakukan Penggandaan dan/atau Penggunaan secara Komersial Ciptaan. Selanjutnya pengelola tempat perdagangan dilarang membiarkan penjualan dan/atau penggandaan barang hasil pelanggaran 
Hak Cipta dan/atau Hak Terkait di tempat perdagangan yang dikelolanya. Jika terbukti melanggar maka pengelola tempat perdagangan dalam segala bentuknya yang dengan sengaja dan mengetahui membiarkan penjualan dan/atau penggandaan barang hasil pelanggaran dipidana dengan denda paling banyak Rp100.000.000,00 (seratus juta rupiah).

\section{Menerbitkan Buku Public Domain}

Buku-buku yang telah berakhir jangka waktu perlindungan hak ekonominya dianggap telah menjadi domain publik (public domain). Hasil karya yang ada dalam domain publik dianggap sebagai bagian dari warisan budaya masyarakat dan setiap orang dapat menggunakannya secara bebas dan legal untuk tujuan apa pun tanpa perlu meminta izin terlebih dahulu (Fitriayu Penyalai: 14).

Hak eksklusif adalah hak yang sematamata diperuntukkan bagi pemegangnya, sehingga pemegang hak dapat mencegah orang lain untuk meniru atau menggunakan tanpa izin royalti. Apabila masa perlindungan telah habis, maka hak ekslusif yang bersifat ekonomis menjadi lenyap, maka si pemilik hak cipta tidak lagi dilindungi dalam penggunaan haknya berarti hak ekslusifnya hilang dan pihak lain dapat mempergunakan ciptaan tersebut secara bebas, tanpa izin dan tanpa royalti. Lenyapnya hak eksklusif penguasaan ciptaan yang telah habis masa perlindungannya beralih mempunyai fungsi sosial (Sufariana, 2012: 276).
Masa perlindungan penguasaan suatu ciptaan ialah berbeda-beda. Mengingat konteks penelitian ini ialah tentang ciptaan buku maka pengaturannya bisa dilihat pada Pasal 58 (1) UUHC 2014 tentang jangka waktu beberapa jenis ciptaan sebagaimana berikut:

"(1) Perlindungan hak cipta atas Ciptaan:

a. buku, pamflet, dan semua hasil karya tulis lainnya;

b. ceramah, kuliah, pidato, dan Ciptaan sejenis lainnya;

c. alat peraga yang dibuat untuk kepentingan pendidikan dan ilmu pengetahuan;

d. lagu atau musik dengan atau tanpa teks;

e. drama, drama musikal, tari, koreografi, pewayangan, dan pantomim;

f. karya seni rupa dalam segala bentuk seperti lukisan, gambar, ukiran, kaligrafi, seni pahat, patung, atau kolase;

g. karya arsitektur;

h. peta; dan

i. karya seni batik atau seni motif lain, berlaku selama hidup Pencipta dan terus berlangsung selama 70 (tujuh puluh) tahun setelah Pencipta meninggal dunia, terhitung mulai tanggal 1 Januari tahun berikutnya."

Dengan berakhirnya jangka waktu perlindungan ciptaan maka habis pula hak eksklusif yang diperoleh pencipta maupun ahli warisnya. Perjanjian untuk memperoleh lisensi tidak lagi diperlukan oleh penerbit sejak ciptaan menjadi public domain. Begitu pula sistem jual putus (sold flat) yang tidak lagi diperlukan oleh penerbit untuk mampu memperoleh seluruh keuntungan dari penjualan buku tanpa harus membagi persentase kepada penulis. Keuntungankeuntungan tersebut dapat diperoleh 
penerbit tanpa perlu khawatir akan menerima sanksi terkait hak eksklusif dari ahli waris.

Tidak sekadar menerbitkan dan mendistribusikan, penerbit juga dapat memanfaatkan ciptaan yang telah menjadi public domain lebih jauh. Salah satunya ialah dengan bekerja sama dengan penerjemah untuk menerjemahkan ciptaan dalam hal buku tersebut berbahasa asing. Perlindungan hak cipta atas karya terjemahan ini diatur pada Pasal 59 (1) yakni selama 50 tahun sejak pertama kali dilakukan pengumuman.

Meski begitu berakhirnya masa hak eksklusif tidak sepenuhnya mengambil hak pencipta atas ciptaannya. Masih terdapat hak moral yang melekat pada diri pencipta meski telah lama meninggal dunia sekalipun. Menurut Pasal 5 (1) UUHC 2014, hak moral ialah hak yang melekat secara abadi pada diri pencipta untuk;

"a. tetap mencantumkan atau tidak mencantumkan namanya pada salinan sehubungan dengan pemakaian Ciptaannya untuk umum; b. menggunakan nama aliasnya atau samarannya; c. mengubah Ciptaannya sesuai dengan kepatutan dalam masyarakat; $d$. mengubah judul dan anak judul Ciptaan; dan e. mempertahankan haknya dalam hal terjadi distorsi Ciptaan, mutilasi Ciptaan, modifikasi Ciptaan, atau hal yang bersifat merugikan kehormatan diri atau reputasinya."

Pemilikan atas hak cipta dapat dipindahkan kepada pihak lain, tetapi hak moralnya tetap tidak terpisahkan dari penciptanya. Hak moral merupakan hak yang khusus serta kekal yang dimiliki si pencipta atas hasil ciptaannya, dan hak itu tidak dipisahkan dari penciptanya. Hak moral ini mempunyai tiga dasar, yaitu hak untuk mengumumkan (the right of publications), hak paterniti (the right of paternity) dua hak tersebut dikenal dengan hak untuk diakui sebagai pencipta (Khoirul Hidayah: 50); dan hak integritas (the right of integrity) yang juga dikenal sebagai hak keutuhan karya (Muhammad Djumhana \& R. Djubaedillah, 1993: 72). Sehingga, meski tidak lagi menerima keuntungan ekonomis, tiap buku yang dicetak tetap harus menampilkan nama sang pencipta.

\section{Jangka Waktu Perlindungan Hak Pencipta Buku Setelah Adanya Perubahan Dari UUHC Sebelumnya ke UUHC 2014}

Meski telah diatur dalam UUHC 2014, tidak berarti pemahaman tentang public domain sudah dipahami secara jelas. Beragamnya jenis jangka waktu perlindungan dalam UUHC bisa dianggap menjadi kendala bagi para pihak untuk memahami betul tiap-tiap masa public domain suatu ciptaan. Misalnya pada Pasal 58 (1) yang mengatur berakhirnya jangka waktu perlindungan ialah 70 tahun sejak pencipta meninggal dunia, yang berbeda dengan Pasal 58 (3) dan 59 (1) (untuk karya fotografi, sinematografi, dan lain-lain) yang mengatur selama 50 tahun sejak pertama ciptaan diumumkan. Belum lagi jika ditambah karya seni terapan yang diatur dalam Pasal 59 (3) yang jangka waktu perlindungannya berakhir 25 tahun sejak pertama kali 
diumumkan.

Perbedaan paham ini juga dapat dilihat dalam sebuah distributor buku yang juga memiliki usaha penerbit besar, Gramedia Pustaka Utama. Melalui situs web gramedia.com (lihat: gramedia.com https://www.gramedia.com/blog/penjel asan-buku-sastra-klasik-sebagai-publicdomain/\#gref) dipaparkan bahwa definisi dari buku public domain sebagai berikut, "Dalam dunia penulisan, bukubuku yang disebut public domain adalah buku-buku yang tentunya penulisnya sudah tidak ada dan juga tidak memiliki ahli waris. Sehingga penerbit manapun bisa merilis ulang atau mencetak ulang, termasuk menerjemahkannya ke dalam bahasa lain, tanpa perlu membeli hak ciptanya." Definisi tersebut tentu berbeda dengan definisi hukum seperti yang telah dipaparkan di atas bahwa berakhirnya hak eksklusif tidaklah terkait dengan ada atau tidaknya penulis dan ahli waris, melainkan pada jangka waktu perlindungan yang telah ditetapkan Pasal 58 (1).

Namun sebenarnya terdapat perbedaan paham pengaturan tentang public domain yang lebih umum terjadi di kalangan umum dan penerbit. Bukan hanya sekadar berapa lama jangka waktu perlindungan hak atas ciptaan, tetapi juga tentang bagaimana mengimplementasikan perubahan peraturan tersebut dari Undang-Undang sebelumnya ke UUHC 2014. Khususnya terkait perubahan jangka waktu perlindungan bagi buku yang penciptanya telah meninggal lebih 50 tahun namun kurang dari 70 tahun sebelum lahirnya UUHC 2014.

Maksud dari paragraf di atas dapat dilihat pada banyaknya perbedaan pemahaman bagi beberapa pihak tentang implementasi jangka waktu perlindungan ciptaan. Misalnya pada 1 Januari 2020 lalu, kala terdapat beberapa pihak yang merayakan berlalunya masa perlindungan hak pada buku Chairil Anwar dan Tan Malaka (Lihat: pdday.org https://www.pdday.org/events/publicdomain-day-indonesia-avros-parkmedan-medan-north-sumatraindonesia/). Perayaan tersebut dilakukan karena menganggap jika menurut UUHC 2014 maka ciptaan kedua penulis berakhir 70 tahun setelah meninggal dunia.

Tan Malaka selaku Penulis Madilog dan Dari Pendjara ke Pendjara meninggal dunia pada tahun 21 Februari 1949. Pada tahun yang sama, Chairil Anwar yang menciptakan kumpulan puisi berjudul $A k u$ juga meninggal dunia. Jika menilik pada Pasal 26 (1) UUHC 1997 yang berlaku masa itu maka masa habis perlindungan hak cipta Tan Malaka dan Chairil Anwar ialah pada 1 Januari 1950 bukan 1 Januari 2020.

Begitu juga penulis Abdul Moeis selaku pencipta novel Salah Asuhan. Jika menilik pada tahun Ia meninggal dunia yaitu pada 17 Juli 1959 maka seharusnya buku-buku ciptaannya telah menjadi public domain pada 1 Januari 2010. Hal ini sesuai dengan pengaturan Pasal 29 (1) UUHC 2002 yang mengatakan bahwa hak atas beberapa ciptaan termasuk buku berlaku selama hidup pencipta dan 
terus berlangsung hingga 50 tahun setelah pencipta meninggal dunia. 1 Januari tahun berikutnya dipilih karena sesuai dengan ketentuan Pasal 34 (b) UUHC 2002 agar tidak mengurangi hak pencipta atas jangka waktu perlindungan hak cipta yang terhitung sejak lahirnya suatu ciptaan.

Habisnya hak atas ciptaan mereka sebelum lahirnya UUHC 2014 membuat buku-buku karangan mereka telah terlebih dahulu menjadi public domain. Berbeda apabila jika Penulis yang telah meninggal tersebut jangka waktu perlindungannya masih berlangsung pada tahun 2014. Misalnya Asmaraman S. Kho Ping Hoo, penulis serial silat $\mathrm{Bu}$ Kek Sian Su yang wafat pada tahun 1994. Saat UUHC 2014 diundangkan, jangka waktu perlindungan penulis tersebut masih tersisa 30 tahun lebih. Karena hak ekonominya masih berlangsung tersebutlah maka perlindungan hak cipta Asmaraman S. Kho Ping Hoo mengikut kepada UUHC 2014 yakni selama 70 tahun setelah Ia meninggal dunia.

Alasan mengapa ketentuan karangan yang telah terlanjur menjadi public domain tidak mengikuti aturan UUHC 2014 tidak lepas dengan ketentuan asas non retroaktif. Ketentuan ini didasari oleh adanya Pasal 28I Undang-Undang Dasar RI Tahun 1945 yang berbunyi:

"Hak untuk hidup, hak untuk tidak disiksa, hak kemerdekaan pikiran dan hati nurani, hak beragama, hak untuk tidak diperbudak, hak untuk diakui sebagai pribadi di hadapan hukum, dan hak untuk tidak dituntut atas dasar hukum yang berlaku surut adalah hak asasi manusia yang tidak dapat dikurangi dalam keadaan apapun"

Hak untuk tidak dituntut atas dasar hukum yang berlaku surut merupakan asas dalam hukum pidana. Larangan keberlakuan surut ini untuk menegakkan kepastian hukum bagi penduduk, yang selayaknya ia harus tahu perbuatan apa yang merupakan tindak pidana atau tidak (Wirjono Prodjodikoro: 2013). Baik pada tataran internasional maupun nasional, asas ini dimaksudkan untuk menghormati dan melindungi hak-hak asasi manusia, terutama dari tindakantindakan penyalahgunaan kekuasaan oleh penguasa. Setiap individu perlu diberikan kepastian hukum atas hidup dan kehidupannya, supaya mereka bisa menjalaninya dengan aman, damai, dan sejahtera (I Wayan Parthiana, 203: 103:104).

Jika Pasal 58 (1) UUHC 2014 berlaku surut dan mengikat pada ciptaan yang telah menjadi public domain maka sanksi pidana yang diatur dalam peraturan perundang-undangan ini juga bisa mengikat. Berbagai tindakan pihak-pihak yang telah telanjur menikmati buku yang sebelumnya telah menjadi public domain dapat dipidana sebagaimana diatur Pasal 113 (3) UUHC 2014. Pengaturan ini juga akan merugikan para penerbit yang telah mereproduksi buku-buku public domain dalam jumlah besar karena dapat diminta pertanggungjawaban royalti oleh ahli waris pencipta.

Selain asas retroaktif alasan lain 
mengapa UUHC 2014 tidak berlaku bagi karya yang terlebih dahulu menjadi public domain adalah tidak adanya ketentuan peralihan yang menyebutkan tentang perubahan berakhirnya jangka waktu perlindungan ini. Melalui Pasal 122 UUHC 2014, ketentuan peralihan terhadap ciptaan buku hanya diberikan kepada perjanjian jual putus yang baru diberikan jangka waktu 25 tahun. Sebaliknya, pada Pasal 74 (1) (b) UUHC telah dijelaskan bahwa kekuatan hukum pencatatan ciptaan sebagaimana dimaksud dalam Pasal 58 akan hapus jika waktunya terlampaui.

\section{KESIMPULAN}

Berdasarkan hasil penelitian dan pembahasan di atas bisa ditarik kesimpulan bahwa:

1. UUHC 2014 tidak memberikan larangan bagi penerbit untuk memanfaatkan buku yang telah menjadi public domain. Penerbit diperbolehkan untuk memanfaatkan hak ekonomi tanpa harus membayar royalti kepada ahli waris. Meskipun di sisi lain, pencipta juga tetap memiliki hak moral yang tidak boleh dilanggar oleh penerbit yang ingin memanfaatkan ciptaannya.

2. Penulis buku yang telah meninggal dunia sebelum tahun 1964 dan telah berakhir hak atas ciptaannya sebelum UUHC 2014 diundangkan tidak lagi memiliki hak ekonomi atas ciptaannya. Hak ciptanya tetap berlangsung selama 50 tahun setelah si penulis meninggal dan ciptaannya telah menjadi public domain. Sebaliknya, penulis yang belum genap 50 tahun meninggal dunia saat UUHC 2014 diundangkan memperoleh perpanjangan hak atas ciptaan sampai 70 tahun setelah meninggal dunia.

\section{DAFTAR PUSTAKA}

Ashilby. (2016). Hukum Hak Cipta (Tinjauan Khusus Performing Right Lagu Indie Berbasis Nilai Keadilan). Yogyakarta: Genta Pubishing

Djumhana, Muhammad \& Djubaedillah, R. (1993). Hak Milik Intelektual (Sejarah, Teori dan Prakteknya di Indonesia). Bandung: Pt. Citra Aditya Bakti

Hidayah, Khoirul. (2012). Hukum HKI (Hak Kekayaan Intelektual di Indonesia). Malang: UIN-Maliki Press

Marzuki, Peter Mahmud. (2005). Penelitian Hukum. Jakarta: Kencana Prenada

Mashdurohatun, Anis (2018). Hak Cipta Atas Buku: Model Fair Use/Fair Dealing. Depok: Rajawali Pers

Nanda Hadiyanti, gramedia.com, Tahukah Kamu Apa Itu Buku Public Domain?

https://www.gramedia.com/blog/penjel asan-buku-sastra-klasik-sebagai-publicdomain/\#gref terakhir diakses pada Selasa, 15 Desember 17:21 WITA.

Parthiana, I Wayan (2003). Hukum Pidana Internasional dan Ekstradisi. Bandung: Yrama Widya

PDDAY, "Public Domain Day Indonesia, AVROS Park Medan, Medan, North 
Sumatra, Indonesia", https://www.pdday.org/events/publicdomain-day-indonesia-avros-parkmedan-medan-north-sumatraindonesia/ terakhir diakses pada Selasa 15 Desember pukul 08:00 WITA.

Penyalai, Fitriayu. (2020). Domain Publik di Indonesia. Jakarta: Goethe-Institut

Prodjodikoro, Wirjono. (2003). AsasAsas Hukum Pidana di Indonesia. Bandung: Refika Aditama

Sufariana. (2012). "Hak Prioritas dan Hak Eksklusif dalam Perlindungan HKI", ADIL, Jurnal Hukum, Volume 3 Nomor 2 